\title{
Preparation and Properties of Purified Phytase from Oakbug Milkcap (Lactarius Quietus) Immobilised on Coated Chitosan with Iron Nano Particles and Investigation of Its Usability in Food Industry
}

\author{
Hicran Onem ${ }^{1}$, Hayrunnisa Nadaroglu ${ }^{1,2, *}$ \\ ${ }^{1}$ Ataturk University, Faculty of Engineering, Department of Nano-Science and Nano-Engineering, Erzurum, TURKEY \\ ${ }^{2}$ Ataturk University, Erzurum Vocational Training School, Department of Food Technology, Erzurum, TURKEY \\ *Corresponding author: Hnisa25@yahoo.com
}

Received October 08, 2014; Revised November 06, 2014; Accepted November 19, 2014

\begin{abstract}
In this study, phytase enzyme was purified and characterized from Oakbug Milkcap mushrooms (Lactarius quietus) and the purified phytase enzyme was immobilized on the surface of modified chitosan with nano- $\mathrm{Fe}_{3} \mathrm{O}_{4}$ nanoparticles. The phytase was purified from Oakbug Milkcap mushrooms using ammonium sulphate precipitation in the range of 40-80\%. and DEAE-sephadex ion-exchange chromatography. The purification fold was calculated by determining the activity and amount of protein for each step. The purified phytase enzyme was then immobilized on modified chitosan support material with $\mathrm{Fe}_{3} \mathrm{O}_{4}$ nanoparticles. The optimum pHs for the immobilized and free enzyme were 6.0 and the optimum temperatures were $60^{\circ} \mathrm{C}$. The effects of some metal ions such as $\mathrm{CuCl}_{2}$, $\mathrm{Hg}_{2} \mathrm{Cl}_{2}, \mathrm{FeCl}_{2}, \mathrm{MgCl}_{2}, \mathrm{ZnCl}_{2}, \mathrm{CaCl}_{2}$ were investigated on both the bound and free purified phytase. The molecular weight of the enzyme was determined using the SDS-PAGE electrophoresis method. Finally, we investigated whether or not the immobilized and free enzyme could hydrolyzed the phytic acid in green lentils, red lentils, peas, pinto beans, beans, brass, corn, dried corn, oat, rye, wheat, broad bean, chickpeas and peanuts. It was concluded that the immobilized phytase was quite resistant to temperature, $\mathrm{pH}$ and metal ions and it could be safely used in the hydrolysis of phytic acid in the legumes in the food industry.
\end{abstract}

\section{Keywords: Oakbug Milkcap (Lactarius quietus) mushroom, phytase, phytic acid, immobilization}

Cite This Article: Hicran Onem, and Hayrunnisa Nadaroglu, "Preparation and Properties of Purified Phytase from Oakbug Milkcap (Lactarius Quietus) Immobilised on Coated Chitosan with Iron Nano Particles and Investigation of Its Usability in Food Industry.” Journal of Food and Nutrition Research, vol. 2, no. 12 (2014): 938-945. doi: 10.12691/jfnr-2-12-13.

\section{Introduction}

Phytase (myo-inositol hexakisphosphate phosphohydrolase, EC 3.1.3.8) is an enzyme which catalyzes the hydrolysis reaction of phytic acid (myoinositol hexaphosphate) to inorganic monophosphate, myo-inositol phosphate and free myo-inositol. Phytic acid locates as main storage the source of phosphorus in food material including grains, legumes and oil seeds.

Phytate creates a negative effect on the mineral intake from food. In the blood $\mathrm{pH}$, phytase caused mineral deficiencies in metabolism by causing an insoluble mineral-phytate complex formation with zinc, iron, calcium, magnesium, manganese and copper metal ions. These formations act as both enzyme cofactors and as different metabolic processes. Phytates also completely prevent the formation of phytate-protein complexes of protein and amino acids [1,2].

The phytase enzyme is located in animals, plants, microorganisms and fungi. Phytase was first identified in rice bran in the early twentieh century. It was later identified and determined in animals, plants and microorganisms including bacteria, yeast and fungi. Phytase was purified from many microorganisms including especially Aspergillus niger, Aspergillus terreus, Aspergillus oryzae, Escherichia coli, Emericella nidulans and Thermomyces lanuginosus [3]. The first commercial phytase enzyme was obtained from Aspergillus niger and it was put up for sale in 1991. Phytase enzymes produced from several yeast species such as Saccharomyces cerevisiae, Candida tropicalis,Kluyveromyces fragilis, Torulopsis candida, Debaryomyces castelli and Schwanniomyces castelli were isolated and characterized [4]. In general, humans and animals have endogenous phytase activity and it is less important than plant, yeast, fungi, microbial phytase activity [5].

Phytase was purified and characterized from a few types of mushrooms. These mushrooms were edible and cultured, and included Agrocybe pediades, Cenporia sp., Peniophora lycii, Trametes pubenscens and Agaricus bisporus [6,7]. The phytase was used in many areas such as animal feed, the food industry, the preparation of myo- 
inositol phosphate, the paper industry, soil improvement and the elimination of environmental pollution. In recent years, some studies had been conducted, to find ways reduce the amount of phytate in cereal products.

In this study, the phytase enzyme was purified from edible, non-toxic Oakbug milkcap (Lactarius quietus) mushrooms using ammonium precipitation and DEAESephadex ion-exchange chromatography techniques, then it was immobilized onto the surface of chitosan and modified with nano-magnetite to ensure prolonged usage. The industrial uses of pure enzymes, values of optimum $\mathrm{pH}$, optimum temperature, stable $\mathrm{pH}$, and stable temperature of soluble and immobilized enyzme were determined to make comparisons and optimization of the method. Measurements of the activity of soluble and immobilized enzymes were performed against different metal ions to determine the altered factors of enzyme activity. The their applicability of the degradation of phytate was then investigated in foodstuff cereal origin, using free and immobilized enzymes.

\section{Materials and Methods}

\subsection{Chemicals}

Chemical. Bovine serum albumin (BSA), Na-phytate, xylan, chitin, starch, gelatin, DEAE-sephedex, Sephacryl S-200, ethylene diamine tetra acetic acid (EDTA), dithioerythritol, $\beta$-mercaptoethanol, and agents for SDS-PAGE were purchased from Sigma (USA). Ethanol, sodium acetate $\left(\mathrm{CH}_{3} \mathrm{COONa}\right)$, ammonium sulphate $\left(\left(\mathrm{NH}_{4}\right)_{2} \mathrm{SO}_{4}\right)$, sodium chloride $(\mathrm{NaCl})$, sodium hydrogen phosphate monohydrate $\left(\mathrm{Na}_{2} \mathrm{HPO}_{4} \times \mathrm{H}_{2} \mathrm{O}\right)$, glutaraldehyde were purchased from Merck (Darmstadt, Germany). All other chemicals were of the analytical grade.

\subsection{Plant Material and Storage Conditions}

Oakbug milkcap mushrooms (Lactarius quietus) were collected from Manisa, Turkey and the surrounding area from May to July. They were stored at $-40^{\circ} \mathrm{C}$ until studying. The mushrooms were identified by a botanist.

\subsection{Purification of the Phytase Enzyme from Oakbug Milkcap Mushrooms (Lactarius quietus)}

The phytase enzyme was purified from the mushrooms in two steps. In the first step, the ammonium sulfate precipation was performed in the homogenate of the mushroom in the range of $0-20 \%, 20-40 \%, 40-60 \%, 60-$ $80 \%$ and $80-100 \%$. The precipitate range with the highest activity was detected. Then, the precipitate was dissolved in $20 \mathrm{mM}$ Na-acetate buffer at $\mathrm{pH}$ 5.5. It was then dialyzed against the same buffer $[8,9,10]$.

In the second step, the homogenat was applied to the previously balanced with $20 \mathrm{mM}$ of Na-acetate buffer ( $\mathrm{pH}$ 5.5) and the DEAE -Sephadex column. The column was washed with the same buffer. Phytase was eluted from the column by increasing the ionic strength gradient of the buffer. The activity of the phytase enzyme was determined in the eluates using a Na-phytate substrate. The eluates which showed phytase activiy were combined with each other and the enzyme pool was created $[9,10]$.

\subsection{SDS-PAGE Electrophoresis}

The Laemmli method was used to determine the number of subunits of the purified phytase from Oakbug milkcap mushrooms (Lactarius quietus) [11]. Sodium dodecyl sulfate gel electrophoresis (SDS-PAGE) was performed in two different acrylamide concentrations with $3 \%$ stacking gel and $10 \%$ seperation gel.

\subsection{Immobilization of the Purified Phytase Enzyme}

\subsubsection{Preparation of the Chitosan Particles}

The method proposed by Chiu et al. [12] was used in the preparation of the chitosan particles. The chitosan was stirred with acetic acid for three hours. Then, the mixture was neutralized by adding $1 \mathrm{~N} \mathrm{NaOH}$ in an ethyl alcohol medium. Chitosan molecules were then washed with distilled water. The moleculs were treated with a 5\% glutaraldehyde solution for 4 hours to bind the amino group to the chitosan molecule. Finally, chitosan molecules were washed with distilled water under a vacuum to remove the non-binding glutaraldehyde from the medium.

\subsubsection{Preparation of Nano-Magnetite Chitosan Particles and Immobilization of the Purified Phytase Enzyme}

The magnetic property of the surface of chitosan particles was allowed by treating with dispersed $\mathrm{Fe}_{3} \mathrm{O}_{4}$ in distilled water. After treating, the chitosan with nano particles, the chitosan was washed with distilled water to remove the non-binding nano particles. Then, the wet precipitate was dried over s 72 hour time period at $40^{\circ} \mathrm{C}$ and it was stored at $4^{\circ} \mathrm{C}$ for use in experimental studies.

The purified phytase enzyme from Oakbug Milkcap (Lactarius quietus) was immobilized to the surface of modified with $\mathrm{Fe}_{3} \mathrm{O}_{4}$ NPs and activated with the glutaraldehyde chitosan in the Na-acetate buffer solution (pH 5.5), which contained $25 \mathrm{mM} \mathrm{NaCNBH}_{3}$. The amount of protein was determined in the reaction medium at different time intervals, by using the Warburg and Bradford methods. The amount of the binding phytase enzyme was determined against time.

\subsubsection{Determination of the Optimum Conditions for the Immobilization of the Purified Phytase Enzyme Onto the Modified Chitosan with $\mathrm{Fe}_{3} \mathrm{O}_{4} \mathrm{NPs}$}

The following optimization procedure were performed to determine the most suitable immobilization conditions of the phytase enzyme to support material for all studies of immobilization.

The most appropriate immobilization $\mathrm{pH}$ was determined mading immobilization in the $\mathrm{pH}$ range of 5.0 to 8.0. The most appropriate immobilization temperature was determinated by carrying out immobilizations at $10^{\circ} \mathrm{C}$, $15^{\circ} \mathrm{C}$ and $20^{\circ} \mathrm{C}$ in a previously determined $\mathrm{pH}$.

The phytase binding efficiency $(\mathrm{E})$ is defined as follows:

$$
\mathrm{E}=\left(\mathrm{C}_{1}-\mathrm{C}_{\mathrm{o}}\right) / \mathrm{C}_{1}
$$

where $\mathrm{C}_{1}$ and $\mathrm{Co}$ are the amounts of phytase protein in the solution before and after immobilization, respectively. The activity amount of the immobilized phytase was calculated as follows: 
Immobilized phytase $=\mathrm{A} /\left(\mathrm{A}_{1}-\mathrm{A}_{\mathrm{o}}\right)$

where $A$ is the activity of the immobilized phytase and $A_{1}$ and $A_{0}$ are the activities of the free phytase in solution before and after immobilization, respectively.

\subsection{Determination of the Phytase Activity}

Phytase activity was determined by measuring the amount of inorganic phosphate which was hydrolyzed from sodium phytate. The amount of phosphate hydrolyzed in the medium was determined by assaying the changes of absorbance at $700 \mathrm{~nm} \mathrm{[13].} \mathrm{One} \mathrm{unit} \mathrm{of}$ phytase activity (1 EU) was defined as the amount of enzyme that released $1 \mu \mathrm{mol}$ inorganic phosphate at optimum conditions in a one minute reaction.

\subsection{Protein Determination}

The protein concentration of the samples was determined spectrophotometrically using the Bradford method [14]. Bovine serum albumin (BSA) was used as a standard.

\subsection{Determination of the Optimal $\mathrm{pH}$ for Activity and Stability}

The optimum $\mathrm{pH}$ was determined at $50^{\circ} \mathrm{C}$ using different buffers: $50 \mathrm{mM}$ citric acid buffer for $\mathrm{pH}$ 3.0-5.0, $50 \mathrm{mM}$ MES buffer for $\mathrm{pH}$ 5.0-7.0, and $50 \mathrm{mM}$ Tris buffer for $\mathrm{pH}$ 7.0-9.0. The immobilized and free-form phytase were suspended in each buffer at different $\mathrm{pH}$ levels to give an activity of $30 \mathrm{U} / \mathrm{mL}$. The $\mathrm{pH}$ stability was tested in $100 \mathrm{mM}$ buffer incubated for $4 \mathrm{~h}$ at $4^{\circ} \mathrm{C}$.

\subsection{Determination of Temperature Optima and Thermal Stability}

The various temperatures $\left(20-90^{\circ} \mathrm{C}\right)$ were tested in 50 $\mathrm{mM}$ Na-acetate buffer ( $\mathrm{pH}$ 5.0) to determine the optimal temperature for the enzyme reaction. To determine the thermostability of the enzyme, thermal challenges at different temperatures $\left(60^{\circ} \mathrm{C}, 70^{\circ} \mathrm{C}, 80^{\circ} \mathrm{C}\right.$, and $\left.90^{\circ} \mathrm{C}\right)$ were performed in $50 \mathrm{mM}$ acetate buffer ( $\mathrm{pH}$ 5.0). Immediately afterwards, the heat-treated enzymes were place on ice. Residual phytase activity was measured at $50^{\circ} \mathrm{C}$ and $\mathrm{pH}$ 5.0, as described previously [14]. Each treatment was done a minimum of three times.

\subsection{Effect of Some Metal Ions}

The influence of various metal ions such as $\mathrm{Zn}^{2+}, \mathrm{Cu}^{2+}$, $\mathrm{Co}^{2+}, \mathrm{Mn}^{2+}, \mathrm{Ca}^{2+}$ and $\mathrm{Fe}^{2+}$ at concentrations of 1 and 5 $\mathrm{mM}$ on enzyme activity was investigated by preincubating the phytase with different compounds for $10 \mathrm{~min}$ at room temperature. Residual activity was calculated against control.

\subsection{Hydrolysis of Phytate in Some Cereals}

The legumes were collected at local markets such as green lentils, red lentils, peas, pinto beans, beans, brass, corn, dried corn, oat, rye, wheat, broad bean, chicpes and peanuts were used for hydrolyzing the phytate. First of all, the cereals were washed elaborately; then they were kept in air to dry, and they were homogenized. Into the $5 \mathrm{~g}$ legume sample homogenate, $2 \mathrm{~mL}$ free enzyme (30 U/mL) solution was added. Also, the same experimental mixture was created for immobilized phytase enzyme. At $5.0 \mathrm{pH}$ value, the legumes homogenates were processed with free phytase and immobilized phytase enzyme for 4 hour at $50^{\circ} \mathrm{C}$. Then, the amount of free phosphorus was determined by assaying the standart activity against blank sample which was consisted of distilled water [14]. The amount of phosphorus was calculated by using calibration curve. A control was prepared without added enzyme for all the assays.

\section{Results and Discussion}

Phytases (myo-inositol hexakisphosphate phosphohydrolase) [EC 3.1.3.8] belong to the class of fosfomono esterase of enzymes and thwy are enzyme which catalyze hydrolysis reaction to phosphate, inositol and phosphate result in sequentially hydrolysis groups of organophosphate of phytic acid $[15,16]$.

\subsection{Purification and Characterization of Phytase from Oakbug Milkcap (Lactarius quietus)}

The phytase enzyme was purified in three steps including ammonium sulfate precipitation, DEAEsephadex ion exchance chromatograhy and Sephacryl S200 gel filtration chromatography from Oakbug Milkcap (Lactarius quietus). All purification steps were summarized in Table 1.

Table 1. The purification process of purified phytase enzyme from Oakbug Milkcap (Lactarius quietus)

\begin{tabular}{|c|c|c|c|c|c|c|c|}
\hline \multirow{2}{*}{ Enzyme Fraction } & Volume & Activity & \multicolumn{2}{|c|}{ Total Activity } & \multicolumn{2}{c|}{ Protein } & \multicolumn{2}{c|}{ Ppecific Activity } & \multicolumn{2}{c|}{ Purification } \\
\cline { 2 - 7 } & $\mathrm{mL}$ & EU/mL & EU & $\%$ & (mg/ml) & EU/mg protein & Fold \\
\hline Crude extract & 50 & $1952.6 \pm 0.33$ & $9.8 \times 10^{4}$ & 100 & $195.0 \pm 1.13$ & 10.01 \\
\hline$\left(\mathrm{NH}_{4}\right)_{2} \mathrm{SO}_{4}(40-80 \%)$ & 30 & $1413.1 \pm 0.71$ & $4.24 \times 10^{4}$ & 43.3 & $18.6 \pm 0.25$ & - \\
\hline DEAE-sephadex & 30 & $1016.1 \pm 0.22$ & $3.05 \times 10^{4}$ & 31.1 & $3.12 \pm 0.12$ & 75.97 & 325.7 \\
\hline
\end{tabular}

In the first stage, the crude extract was precipitated between the range of $0-100 \%$ ammonium sulfate saturation. These results showed that phytase enzyme activity was determined the highest rate in the range of 40 $80 \%$ saturation by precipitation. The purified phytase in $43.3 \%$ yield and 7.58-fold purification was applied to a DEAE-sephadex ion exchange column.

In the second step, amonyum sulphate fraction of 40$80 \%$ was applied to the DEAE- sephadex ion exchange column. The phytase was purified more than 32.54 times fold with a yield of $31.1 \%$, and its specific activity was eqivalent to $325.7 \mathrm{EU} / \mathrm{mg}$ protein (Table 1). Phytase enzyme from Oakbug Milkcap (Lactarius quietus) mushroom was purified with anion exchange chromatography and it was presented in Figure 1.

Sodium dodecyl sulfate polyacrylamide gel electrophoresis (SDS-PAGE)'s results were presended for purified the phytase enzyme, $45 \mathrm{kDa}$ consists of one subunit has been identified (Figure 2). 


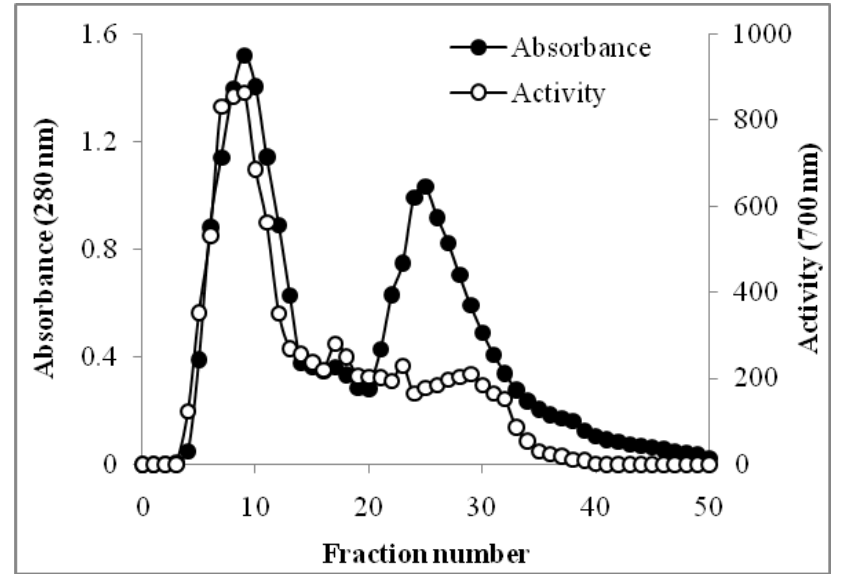

Figure 1. Purification of phytase by ion exchange chromatography using DEAE-sephadex

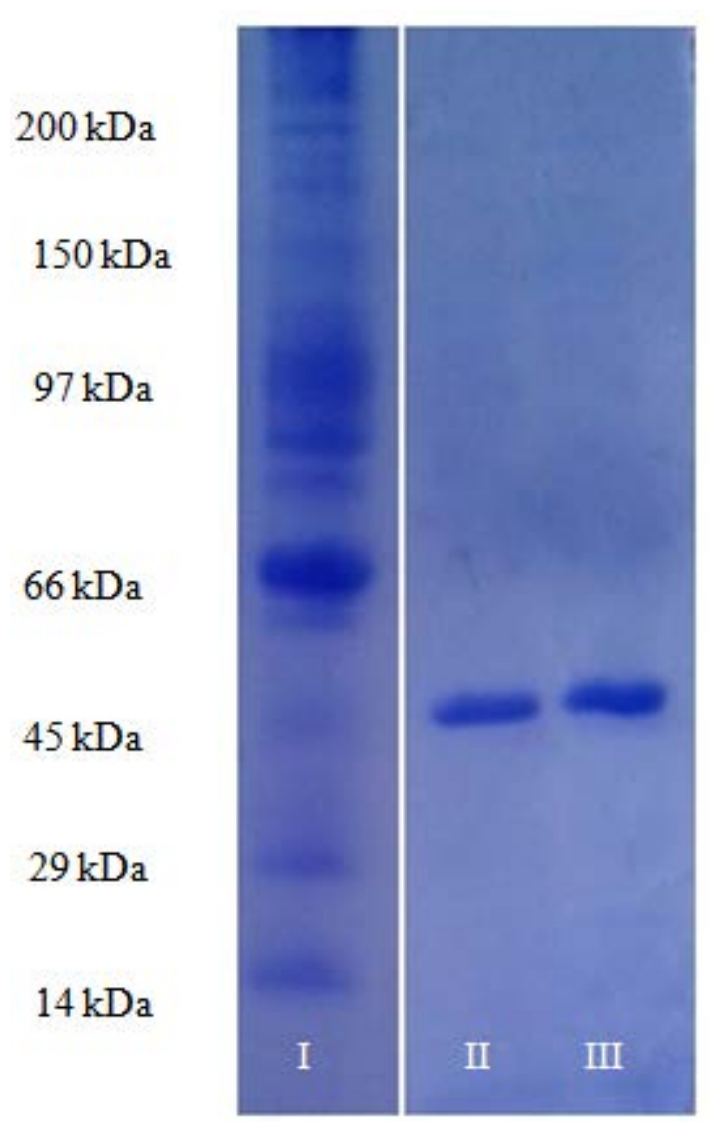

Figure 2. SDS-PAGE electrophoretic pattern of phytase [purified phytase enzyme from Oakbug Milkcap (Lactarius quietus)

Standart protein ( $\beta$-Amylase, sweet potato, $200 \mathrm{kDa}$; alcohol dehydrogenase, yeast, $150 \mathrm{kDa}$ bovine serum albumin, $97.4 \mathrm{kDa}$; rabbit muscle phosphorylase A, 66 $\mathrm{kDa}$; egg ovalbumin, $45 \mathrm{kDa}$; pepsin, $29 \mathrm{kDa}$; carbonic anhydrase); cytochrome c, horse heart $14 \mathrm{kDa}(\mathrm{I})$; Oakbug Milkcap (Lactarius quietus) (II and III)].

To find the molecular weights of the active form of the purified enzyme, Sephadex G-100 gel filtration chromatography was performed and the same results were obtained. Also, molecular weight of thermostable monomeric phytase enzyme purified from the Mycobacterium smegmatis and Escherichia coli was found around $45 \mathrm{kDa}[17,18]$.

Firstly, chitosan was activated by binding the glutaraldehyde to the amino group $\left(-\mathrm{NH}_{2}\right)$ located chitosan for connecting the purified phytase enzyme to the modified chitosan molecules with $\mathrm{F}_{3} \mathrm{O}_{4}$ nano particles. Then, it was provided binding of purified phytase by creating schift base to glutaraldehyde. $\mathrm{NaCNBH}_{3}$ was used for reducting base of schift formed in both of two steps. After synthesized the support material, its surface was coated with $\mathrm{Fe}_{3} \mathrm{O}_{4}$ nanoparticles for purpose gain magnetic feature of chitosan. Made reactions were shown below (1-3).

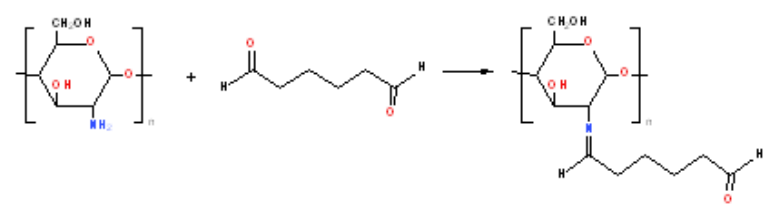

(1)

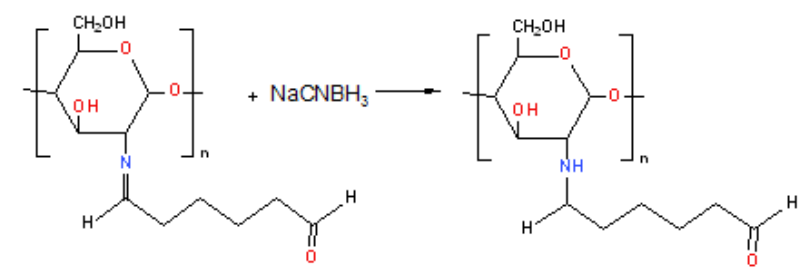

(2)
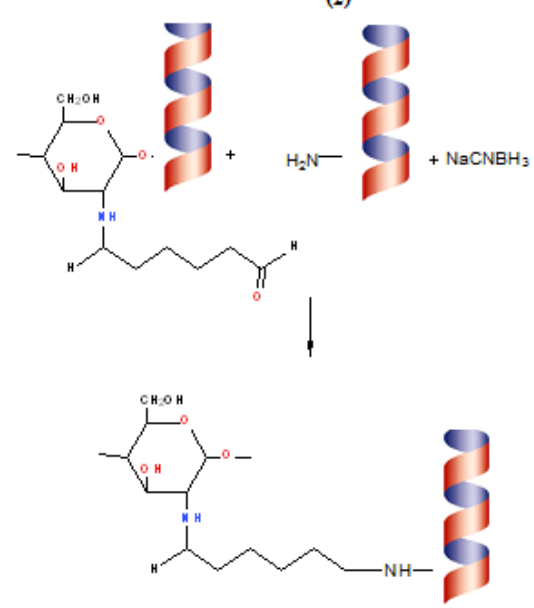

(3)

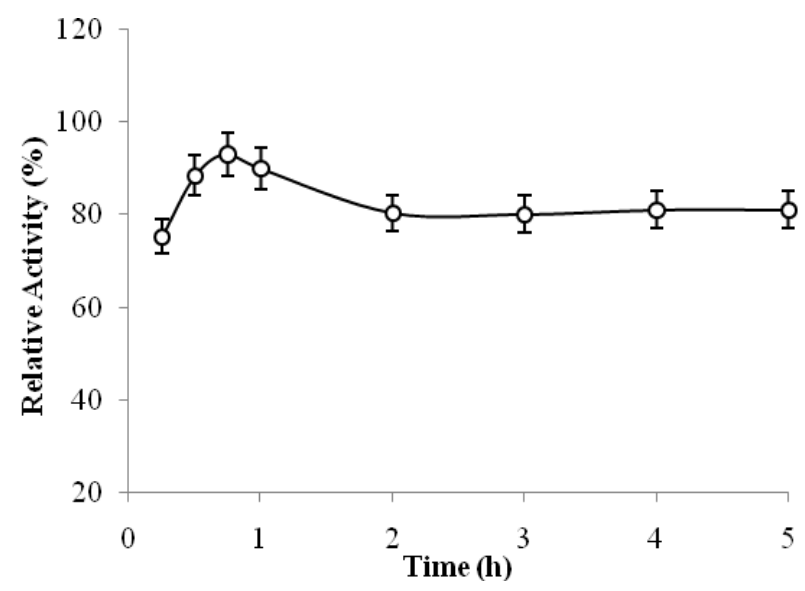

Figure 3. The effect of time to the immobilization of phytase enzyme onto modifed chitosan with nano magnetite

$\mathrm{pH}$ and temperature was primarily determined in order to determined the optimum conditions of covalent immobilization to the surface of magnetized citosan with nano $\mathrm{Fe}_{3} \mathrm{O}_{4}$ of pure phytase enzyme. Pure phytase enzyme were immobilized by using appropriate buffers among $\mathrm{pH}$ 
4-8, and it was calculated relative activity (\%) of immobilized phytase. Accordingly, it was determined that the pure phytase enzyme was connected to support material at the high level at $\mathrm{pH} 5$ and $20^{\circ} \mathrm{C}$. Then, the immobilization was monitored for 5 hours to determine the most approiate immobilization time at $\mathrm{pH} 5$ and $20^{\circ} \mathrm{C}$. It was determined that purified phytase enzyme was connected to magnetized citosan with nano $\mathrm{Fe}_{3} \mathrm{O}_{4}$ support material after 1 hour at the rate of $82.5 \%$ (Figure 3 ).

\subsection{Structural Characterization of Support}
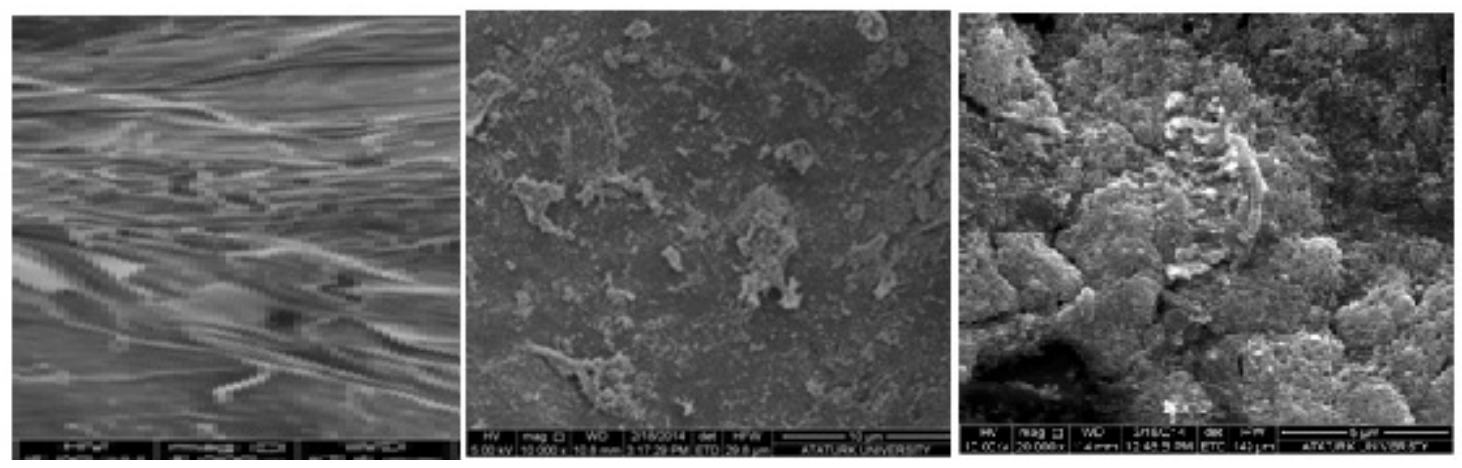

Figure 4. SEM images I: nature chitosan; II: modified chitosan with nano magnetite; III: purified phytase immobilized modified chitosan with nano magnetite

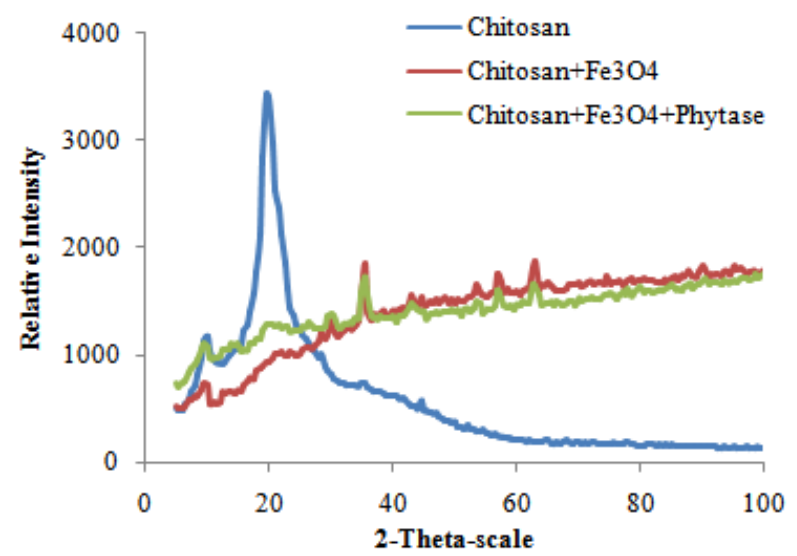

Figure 5. XRD photographs for nature chitosan; modified chitosan with nano magnetite; purified phytase immobilized modified chitosan with nano magnetite

\subsection{X-Ray Diffraction (XRD) Analysis}

Figure 5 shows XRD patterns of nature chitosan; modified chitosan with nano magnetite; purified phytase immobilized modified chitosan with nano magnetite. XRD patterns chitosans are illustrated in Figure 5. The XRD pattern of chitosan exhibits broad diffraction peaks at $2 \theta=$ $9,5^{\circ}$ and $19,5^{\circ}$ which are typical fingerprints of crystal chitosan [19]. In the XRD pattern of prepared $\mathrm{Fe}_{3} \mathrm{O}_{4}$ modified chitosan NPs and purified phytase immobilized modified chitosan with nano magnetite, the peak corresponding to chitosan could be seen at around $2 \theta=$ $20.0^{\circ}$, but it became much lower and wider. Also, five diffraction peaks were observed at $2 \theta=35.5^{\circ}, 44.5,54.5$, $57.5^{\circ}, 63.0^{\circ}$. These peaks are belong to typical fingerprints of $\mathrm{Fe}_{3} \mathrm{O}_{4}$ NPs [20].

\subsection{FTIR Analysis}

Structure of chitosan, modified chitosan with nano magnetite and purified phytase immobilized modified chitosan with nano magnetite at SEM images were shown in Figure 4a-c. The thickness of the wall is about $20 \sim 30$ $\mathrm{nm}$, the pore size is about $0.5 \sim 1 \mu \mathrm{m}$. From the SEM image, it was obseved that the support material was finepore structure and its structure was appropriated to modify with nanomaterials and to immobilization with phytase enzyme. In addition, it had a large-sized support and structural stability. 
in the functional biomass groups of magnetic $\mathrm{Fe}_{3} \mathrm{O}_{4}-$ chitosan nanoparticles after immobilization of phytase enzyme. The results of FT-IR spectrums indicated that chitosan was coated to the magnetic $\mathrm{Fe}_{3} \mathrm{O}_{4}$ nanoparticles and phytase enzyme was immobilized onto the magnetic $\mathrm{Fe}_{3} \mathrm{O}_{4}$-chitosan nanoparticles successfully.
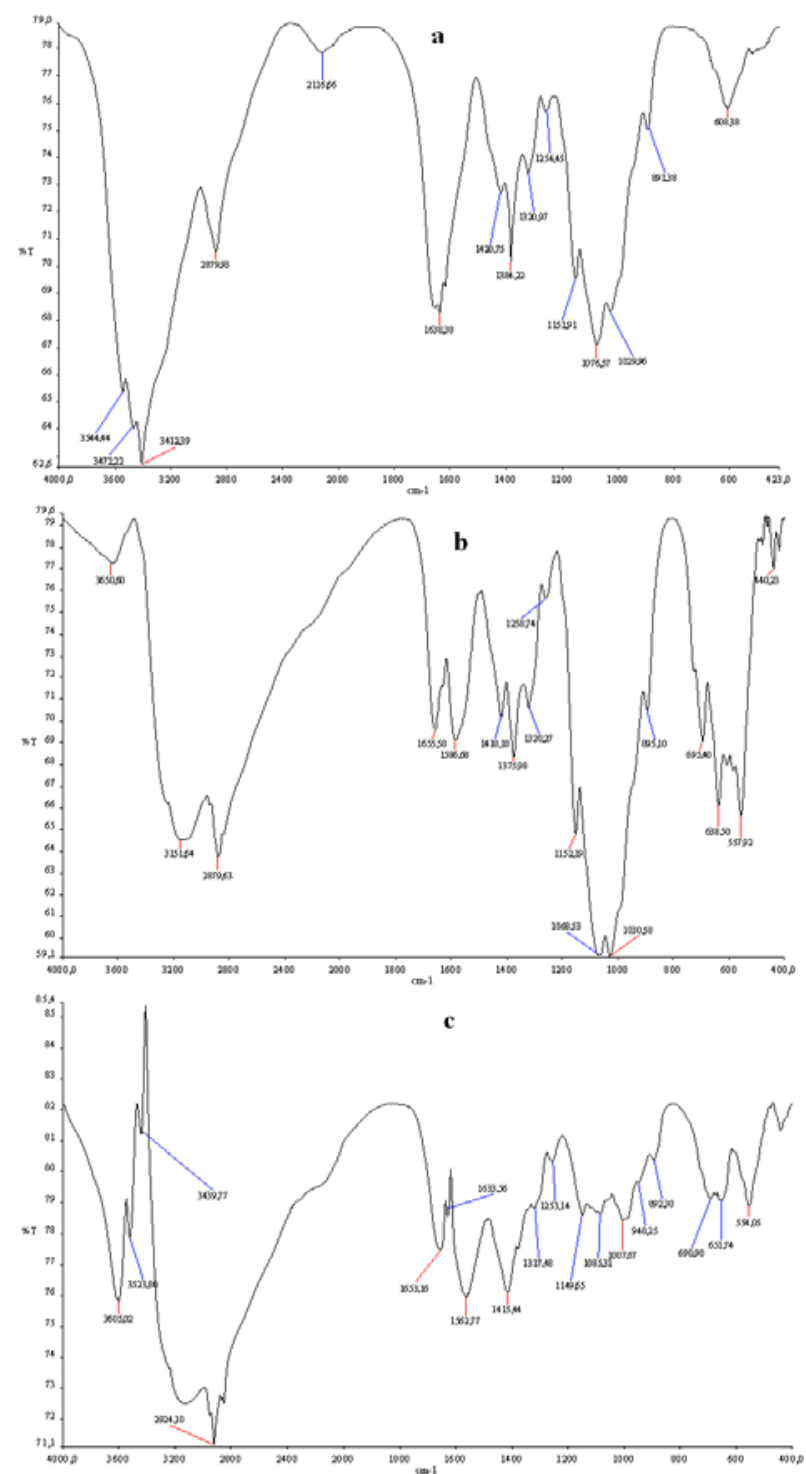

Figure 6. FT-IR spectrum of nature chitosan (a), modified chitosan with nano magnetite (b), immobilized chitosan with purified phytase from Oakbug milkcap (Lactarius quietus) (c)

\subsection{Biochemical Properties of Free and Immobilized Phytase}

\subsubsection{Loading Amount and Activity of Immobilized Phytase}

The average loading amount of modified support is about ng/g. The phytase enzyme was bound to surface as covalent, it was also bound there with weak bonds with wander walls bonds and binding rate was increased. In a study, it was observed that the enzyme was connected to modified support using nanostructure at most amount and powerfully. This research was supported our work [23].

\subsection{Effect of Incubation Time, pH and Temperature}

\subsubsection{Effect of Reaction Temperature}

The reaction was carried out from 10 to $90^{\circ} \mathrm{C}$ using Nafitat as a substrate at $\mathrm{pH} 5.0$ for $30 \mathrm{~min}$ incubation time for free and immobilized phytase enzyme. The maximum phytase activity for free and immobilized phytase was found at $50^{\circ} \mathrm{C}$. But, it was determined that both their activity were decreased in higher temperatures (Figure 7a.).
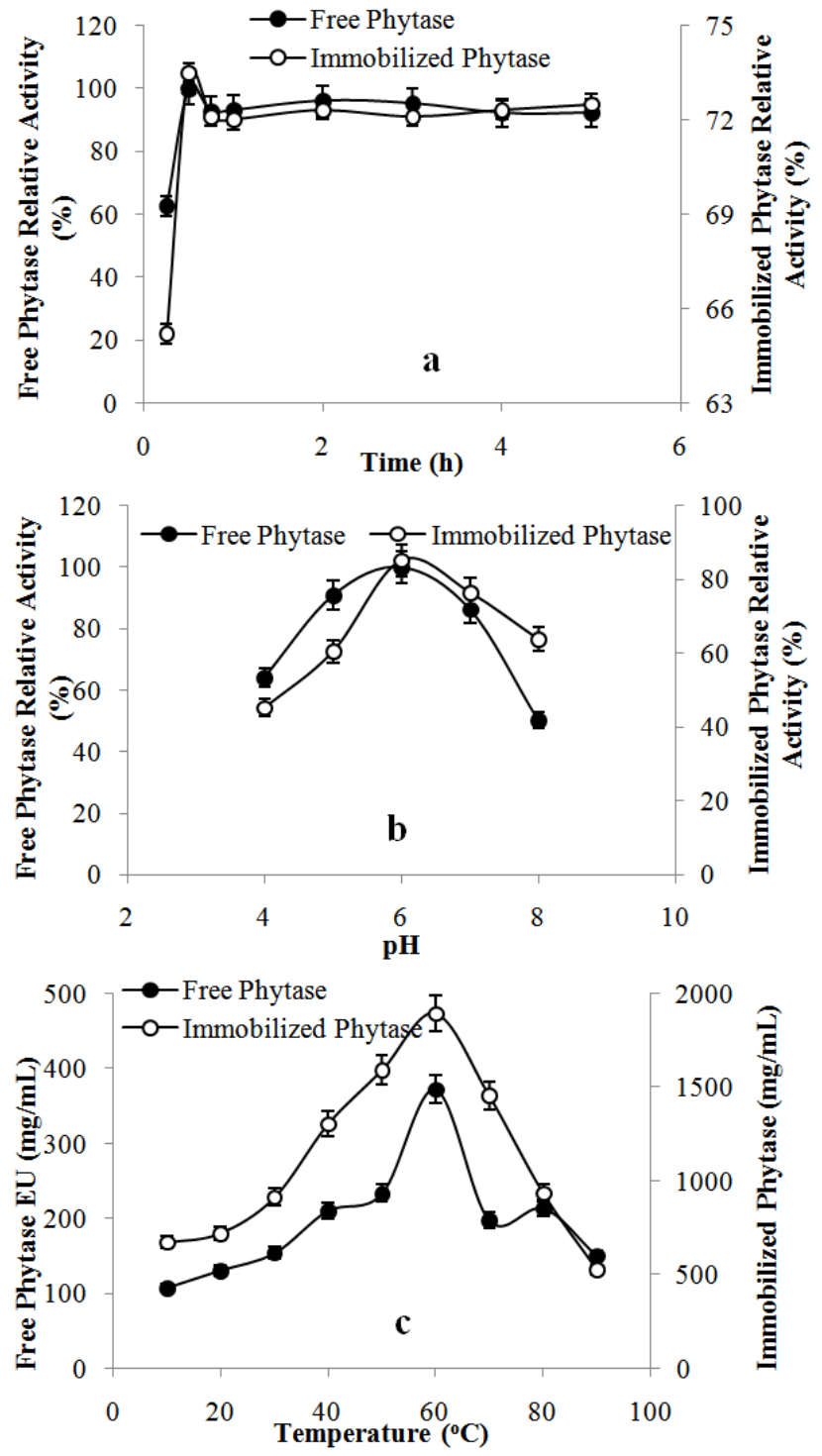

Figure 7. Optimization of purified and immobilized phytase enzyme activity. Reaction condition for a reaction time optimization (temperature $60^{\circ} \mathrm{C}$ and $\mathrm{pH} 6.0$ ), b pH optimization (temperature $60^{\circ} \mathrm{C}$ and incubation time $30 \mathrm{~min}$ ), and c temperature optimization ( $\mathrm{pH} 6.0$ and incubation time $30 \mathrm{~min}$ )

\subsubsection{Effect of pH}

Enzyme substrate reaction was done at $50^{\circ} \mathrm{C}$ for $30 \mathrm{~min}$ varing the $\mathrm{pH}$ from 4.0 to 8.0 . Optimum $\mathrm{pH}$ was found as 5.0 for free and immobilized phytase enzyme (Figure $7 \mathrm{~b}$ ).

\subsubsection{Effect of Reaction Time}

Enzyme substrate reaction was done at $50^{\circ} \mathrm{C}$ and $\mathrm{pH}$ 5.0 during 5 h. For free and immobilized phytase, maximum enzyme activity was found to be at $45 \mathrm{~min}$ incubation time and and reaction was reached to balance at 1 hour (Figure 7c). 


\section{7. pH Stability and Termal Stability}

\subsubsection{Thermal Stability}

Enzymes are composed of protein and they are often sensitive to heat and they can be inhibited. Immobilized enzymes were resistant to high temperatures, so it had

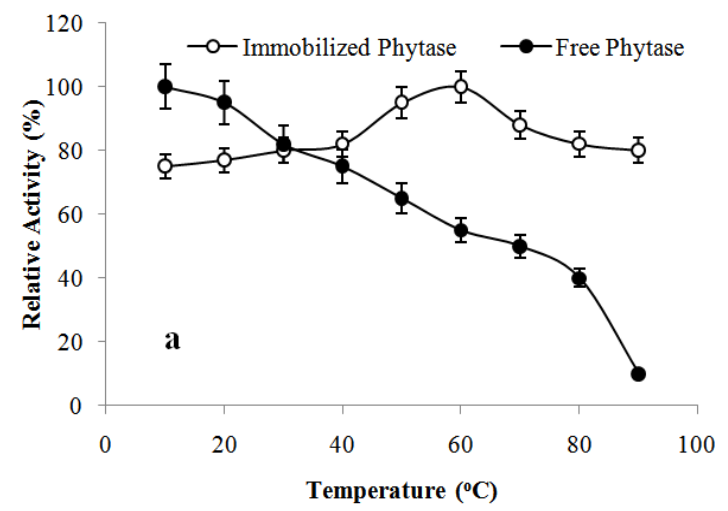

been many advantages for use in applications. The thermo-stability of the immobilized phytase was measured in comparison with free phytase as shown in Figure 8a. The rates of thermal inactivation of the soluble and immobilized enzyme were studied at the temperature range of $20-90^{\circ} \mathrm{C}$ at $\mathrm{pH} 5.0$ in $50 \mathrm{mM}$ Na-acetate buffer.

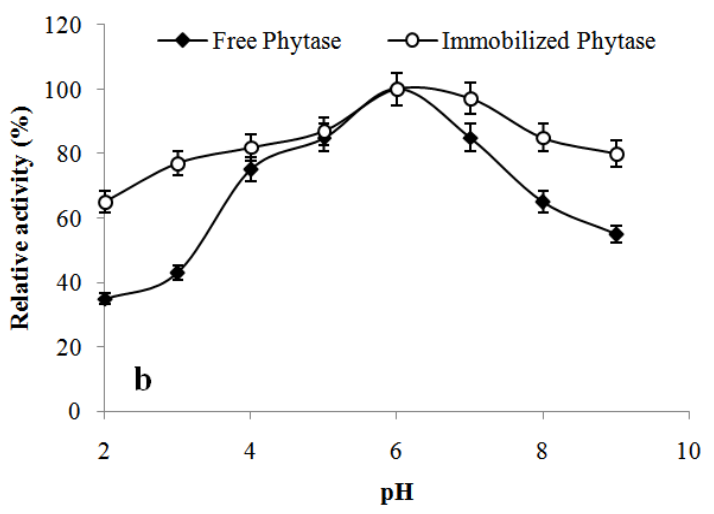

Figure 8. (a) Thermal stability, (b) pH stability for free and immobilized phytase

While free enzyme was losting its activity at approximately rate of $60 \%$, at $80^{\circ} \mathrm{C}$ after heat treatment for 1 hour, immobilized phytase was only losted its activity at $38 \%$ rate. Consequently, covalently linked immobilized phytase onto $\mathrm{Fe}_{3} \mathrm{O}_{4}$ modified chitosan NPs was more resistant to temperature than soluble phytase. When enzyme was covalently bounded onto modified chitosan with nano magnetite, it could be thought that phytase enzyme was protected from environmental factors which was caused conformational changes.

\subsection{1. pH Stability}

Free and immobilized phytase enzyme were incubated for 1 hour at $4^{\circ} \mathrm{C}$ by using buffer of acetate from $\mathrm{pH} 3$ to 5 , phosphate from $\mathrm{pH} 6$ to 7 and Tris/HCI from $\mathrm{pH} 8$ to 9 and their activity were measured after 1 hour and the results are shown in Figure $8 \mathrm{~b}$. It was determined that free enzyme was maintained $43 \%$ rate of its activity while immobilized enzyme was maintaining $77 \%$ rate of its activity at $\mathrm{pH}$ 3. Also, free phytase was maintained 55\% rate of its activity while immobilized phytase was maintained $80 \%$ rate of its activity at $\mathrm{pH} 9.0$. As seen from the results, immobilized phytase enzyme activiy was more stable againts different $\mathrm{pH}$ values according to free enzyme.

\subsection{The Effects of $\mathrm{Fe}^{2+}, \mathrm{Cu}^{2+}, \mathrm{Hg}_{2}{ }^{2+}, \mathrm{Co}^{2+}$, $\mathrm{Mg}^{2+}$ and $\mathrm{Zn}^{2+}$ on Activity of Free and Immobilized Phytase Enzyme}

Effects of $\mathrm{Fe}^{2+}, \mathrm{Cu}^{2+}, \mathrm{Hg}_{2}{ }^{2+}, \mathrm{Co}^{2+}, \mathrm{Mg}^{2+}$ and $\mathrm{Zn}^{2+}$ on activity of free and immobilized purified phytase enzyme from Oakbug Milkcap (Lactarius quietus) mushroom onto nano- $\mathrm{Fe}_{3} \mathrm{O}_{4}-\mathrm{MD}$ CTS were investigated and all results were given in Table 2 as relative activity\%. While all metal ions were higly inhibited to the activity of free phytase enzyme, only $\mathrm{Co}^{2+}$ was higly inhibited immobilized phytase enzyme. While $\mathrm{Hg}_{2}{ }^{2+}$ and $\mathrm{Mg}^{2+}$ ions were increased the activity of immobilized phytase, $\mathrm{Fe}^{2+}$, $\mathrm{Cu}^{2+}$ and $\mathrm{Zn}^{2+}$ aproximately had no effect it. From the results, it was concluded that immobilized phytase enzyme was more resistant to metal ions. Because of this feature of enzyme, immobilized phytase could be found to be highly suitable for industrial application.

Table 2. The effect of some chemical compounds on free and immobilized phytase activity

\begin{tabular}{|c|c|c|c|c|}
\hline $\begin{array}{c}\text { Chemical } \\
\text { Compounds }\end{array}$ & $\begin{array}{c}\text { Concentration } \\
(\mathrm{mM})\end{array}$ & $\begin{array}{c}\text { Free Phytase Relative Activity } \\
(\%)\end{array}$ & $\begin{array}{c}\text { Concentration } \\
(\mathrm{mM})\end{array}$ & $\begin{array}{c}\text { Immobilized Phytase Relative Activity } \\
(\%)\end{array}$ \\
\hline None & - & $100 \pm 0.0$ & - & $100 \pm 0.0$ \\
\hline Fe2+ & 1 & $70.3 \pm 2.01$ & 1 & $89.3 \pm 1.25$ \\
\hline Cu2+ & 1 & $43.3 \pm 2.3$ & 1 & $81.1 \pm 1.02$ \\
\hline Hg22+ & 1 & $105.4 \pm 1.1$ & 1 & $116.8 \pm 0.3$ \\
\hline Co2+ & 1 & $72.97 \pm 1.4$ & 1 & $43.3 \pm 1.15$ \\
\hline Mg2+ & 1 & $59.5 \pm 1.13$ & $13.5 \pm 1.7$ \\
\hline Zn2+ & 1 & $78.4 \pm 0.14$ & 1 \\
\hline
\end{tabular}

\subsection{Hyrolysis of Phytate in Some Cereals}

Phytic acid is capable of making strong chelating. The phytic acid is forming insoluble complexes salts by combined with metal cations $\left(\mathrm{Zn}^{+2}, \mathrm{Cu}^{+2}, \mathrm{Co}^{+2}, \mathrm{Mn}^{+2}, \mathrm{Ca}^{+2}\right.$ ve $\mathrm{Fe}^{+2}$ ) and they prevent metal ions' absorbation from intestinal. Phytates decrease digestibility of protein and amino acid and they lead to negative effect in mineral intake as a result of forming phytate-protein complex which was harder disintegrating by proteolytic enzymes binding endogenous proteases such as especially trypsin and chemotrypsin [24,25]. Therefore, it could be caused iron, calcium and zinc deficiency especially in communities of adopt the type of feeding vegetative [26].

$$
\begin{aligned}
& \text { Phytic acid } \stackrel{\text { Phytase }}{\longrightarrow} \text { Inoganic monophate } \\
& \text { +Myo-inositol phosphate+Free myo-inositol }
\end{aligned}
$$

Due to this reason, phytic acid which was located in the outer shell of grains and cereals was hydrolyzed using free and immobilized phytase enzyme and the results were 
given in Table 3. From the results, it was observed that immobilized phytase enzyme was more effective at the hydrolysis of phytate in dry beans and it was showed the highest effective on beans, wheat and peanuts at the end of 4th as rates of 75.2, 77.8 and $76.7 \%$, respectively. Immobilized phytase enzyme could be used as additive material in bread making, preparation of vegetable protein hydrolyzate products and breakdown of bran in cereals.

Table 3. The hydrolsis of phytate from some legumes using free and immobilized phytase enzymes

\begin{tabular}{|c|c|c|c|c|c|}
\hline \multirow{16}{*}{ 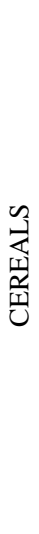 } & & \multicolumn{2}{|c|}{ Free Phytase Activity } & \multicolumn{2}{|c|}{ Immobilized Phytase Activity } \\
\hline & Time (h) & $2 \mathrm{~h}$ & $4 \mathrm{~h}$ & $2 \mathrm{~h}$ & $4 \mathrm{~h}$ \\
\hline & Green Lentils & $26.74 \pm 1.21$ & $43.7 \pm 1.13$ & $38.8 \pm 0.28$ & $56.5 \pm 0.51$ \\
\hline & Red Lentils & $21.0 \pm 0.01$ & $31.93 \pm 1.5$ & $28.3 \pm 1.45$ & $53.2 \pm 0.18$ \\
\hline & Peas & $35.9 \pm 0.52$ & $57.0 \pm 0.32$ & $38.2 \pm 0.22$ & $62.5 \pm 1.3$ \\
\hline & Pinto Beans & $53.13 \pm 0.2$ & $59.44 \pm 0.06$ & $63,5 \pm 0.7$ & $68.7 \pm 0.51$ \\
\hline & Beans & $56.76 \pm 1.16$ & $61.75 \pm 1.0$ & $68,28 \pm 1.05$ & $75.2 \pm 0.15$ \\
\hline & Brass & $18,29 \pm 1.4$ & $27.82 \pm 2.13$ & $33.7 \pm 1.7$ & $47.6 \pm 1.31$ \\
\hline & Corn & $29.01 \pm 0.15$ & $40,68 \pm 1.14$ & $33,3 \pm 0.22$ & $58.4 \pm 2.2$ \\
\hline & Dried Corn & $19.34 \pm 0.15$ & $28.2 \pm 0.36$ & $25.05 \pm 0.03$ & $38,7 \pm 1.13$ \\
\hline & Oat & $20.73 \pm 1.17$ & $32.2 \pm 0.31$ & $26.7 \pm 0.36$ & $42.3 \pm 1.6$ \\
\hline & Rye & $29.38 \pm 4.31$ & $41.4 \pm 2.1$ & $35.1 \pm 0.13$ & $56.8 \pm 1.26$ \\
\hline & Wheat & $60.67 \pm 0.3$ & $63.21 \pm 0.6$ & $63.28 \pm 0.28$ & $77.8 \pm 1.02$ \\
\hline & Broad Bean & $44.45 \pm 0.4$ & $51.34 \pm 1.4$ & $45.8 \pm 1.6$ & $58.7 \pm 0.22$ \\
\hline & Chickpea & $33.93 \pm 0.15$ & $52.29 \pm 0.03$ & $36.4 \pm 0.01$ & $58.1 \pm 1.3$ \\
\hline & Peanuts & $48.66 \pm 1.9$ & $67,99 \pm 0.07$ & $65.6 \pm 0.27$ & $76.65 \pm 1.05$ \\
\hline
\end{tabular}

\section{Conclusion}

The phytase was firstly purified and characterized from Oakbug Milkcap (Lactarius quietus) and immobilized onto modified citosan with magnetite. Purified and immobilized phytase enzyme were found that it had high catalytic activity and it was resistance to metal ions, high temperature and different pHs. Also, it was observed that immobilized enzyme was effective on phytate in dry beans. Due to this reason, the immobilized phytase enzyme onto surface of nano- $\mathrm{Fe}_{3} \mathrm{O}_{4}$-MD CTS could also be used in different industrial areas. This research was focused on the food industry. In this context, it could be had a huge potential for use in the field of food, feed and fertilizer.

\section{References}

[1] Kumar, V., Sinha, A. K., Makkar, H. P. S., Becker, K. 2010. Dietary roles of phytate and phytase in human nutrition: a review. Food Chem. 120 (4), 945-959.

[2] Zhang, G. Q., Dong, X. F., Wang, Z. H., Zhang, Q., Wang, H. X., Tong, J. M. 2010. Purification, characterization, and cloning of a novel phytase with low $\mathrm{pH}$ optimum and strong proteolysis resistance from Aspergillus ficuum NTG-23, Bioresource Technology, 101 (11), 4125-4131.

[3] Greiner, R., Konietzny U. 2006. Phytase for food application. Food Technol. Biotechnol. 442, 125-140.

[4] Nayini, N. R., Markakis, P. 1984. The phytase of yeast. Lebensm.Wiss. Technology, 17, 24-26.

[5] Weremko, D., Fandrejewski, H., Zebrowska, T., Han, K., Kim, J. H., Cho, W. T. 1997. Bioavailability of phosphorus in feeds of plant origin for pigs -Review. Asian-Austral. J. Anim. Sci. 10, 551-566.

[6] Lassen, S. F., Breinholt, J., Ostergaard, P. R., Brugger, R., Bischoff, A., Wyss, M., Fuglsang, C. C. 2001. Appl. Env. Microbiol. 67, 4701-4707.

[7] Collopy, P. D., Royse, D. J. 2004. Characterization of phytase activity fromcultivated ediblemushrooms and their production substrates. J. Agr. Food Chem. 52, 7518-7524.

[8] Nadaroglu, H., Tasgin E. 2013. Purification and characterisation of laccase from Lactarius volemus and its application of removal phenolic compounds from some fruit juices. Int. J. Food Agr. Env. 11 (3\&4), 109-114.

[9] Saribuga, E., Dikbas, N., Nadaroglu, H., Senol M., 2014. Purification, characterization of phytase enzyme from Lactobacillus acidophilus bacteria and determination of it's some kinetic properties. J. Pure Appl. Microbio. 8, 91-96.
[10] Sarıbuga, E., Nadaroglu, H., Dikbas, N., Senol, M., Cetin, B., 2014. Purification, characterization of phytase enzyme from Lactobacillus plantarum bacteria and determination of it's some kinetic properties. Afr. J. Biotechnol. 13 (23), 2373-2378.

[11] Laemmli, D. K. 1970. Cleavage of structural proteins during in assembly of the heat of bacteriophage T4. Nature, London, 227, 680-685.

[12] Chiu, S-H., Chung, T-W., Giridhar, R., Wu, W-T., 2004. Immobilization of $\beta$-cyclodextrin in chitosan beads for separation of cholesterol from egg yolk. Food Res. Int. 37, 217-231.

[13] Iqbal T.H., Lewisi K.O., Cooper B.T. 1994. Phytase activity in the human and rat small intestine. Gut, 35, 1233-1236.

[14] Bradford, M. M. 1976. A rapid and sensitive method for the quantitation of microgram quantites of protein utilizing the principle of protein-dye binding. Anal. Biochem. 7, 248-254.

[15] Konietzny, U., Greiner, R. 2004. Bacterial phytase: Potential application, in vivo function and regulation of its synthesis. Brazilian J. Microbiol. 35, 11-18.

[16] Lei, X. G., Porres, J. M., 2003. Phytase enzymology, applications, and biotechnology. Biotech. Lett. 25, 1787-1794.

[17] Nuge, T., Hashim, Y. Z. H-Y. H., Farouk, A-E. A., Salleh H. M. 2014, Cloning and expression of a novel phytase gene phyMS from Mycobacterium smegmatis, Adv. Enz Res. 2, 27-38.

[18] Ostanin, K., Van Etten, R. L. 1993. Asp304 of Escherichia coli acid phosphatase is involved in leaving group protonation. Turkish J. Biol. Chem. 268, 20778-20784.

[19] Ogawa, K., Hirano, S., Miyanishi, T., Yui, T., Watanabe, T. 1984. A new polymorph of chitosan, Macromol. 17, 973-975.

[20] Cao, C., Xiao, L., Chen, C., Shi, X., Cao, Q., Gao, L. 2014. In situ preparation of magnetic $\mathrm{Fe}_{3} \mathrm{O}_{4} /$ chitosan nanoparticles via a novel reduction-precipitation method and their application in adsorption of reactive azo dye, Powder Tech. 260, 90-97.

[21] Guo, M., Diao, P., Cai, S. 2005. Hydrothermal growth of well aligned $\mathrm{ZnO}$ nanorodarrays: dependence of morphology and alignment ordering upon preparing conditions. J. Solid State Chem. 1786, 1864-1873.

[22] Li, G., Jiang, Y., Huang, K., Ding, P., Chen, J. 2008. Preparation and properties of magnetic $\mathrm{Fe}_{3} \mathrm{O}_{4}$-chitosan nanoparticles, J. Alloy. Compd. 466, 451-456.

[23] Shang, C. Y., Li, W. X., Zhang, R. F., 2014. Immobilized Candida antarctica lipase $\mathrm{B}$ on $\mathrm{ZnO}$ nanowires/macroporous silica composites for catalyzing chiral resolution of $R, S$-2-octanol. Enzyme Microb Tech. In press.

[24] Konietzny, U., Greiner, R. 2003. Phytic acid: Nutritional Impact. In: Encyclopedia of Food Science and Nutrition, B. Caballero, L. Trugo, P. Finglas Eds., Elsevier, London, UK, 4555-4563.

[25] Lopez, H. W., Vallery, F., Levrat-Verny, M. A., Coudray, C., Deminge, C., Emesy, C. 2000. Dietary phytic acid and wheat bran enhance mucosal phytase activity in rat small intestine. J. Nutr. 130, 2020-2025.

[26] Ferguson, E. L., Gibson, R. S., Thomson, L. U., Ounpuu, S. 1989. Dietary calcium, phytate, and zinc intakes and the calcium, phytate, and zinc molar ratios of the diets of a selected group of East African children. Am. J. Clin. Nutr. 50, 1450-1456. 